\title{
CD40 stimulation induces differentiation of acute lymphoblastic leukemia cells into dendritic cells
}

\author{
Włodzimierz Łuczyński ${ }^{1 \bowtie}$, Anna Stasiak-Barmuta², Elżbieta Iłendo³, \\ Maryna Krawczuk-Rybak ${ }^{1}$, Iwona Malinowska ${ }^{4}$, Małgorzata Mitura-Lesiuk ${ }^{5}$, \\ Adam Parfieńczyk ${ }^{6}$ and Marcin Szymański ${ }^{7}$ \\ ${ }^{1}$ Department of Pediatric Oncology, ${ }^{2}$ Department of Flow Cytometry, ${ }^{3}$ Department of Cytogenetics, ${ }^{6}$ Department \\ of Nuclear Medicine, ${ }^{7}$ Students Scientific Section at the Department of Pediatric Oncology, Medical University \\ of Białystok, Poland; ${ }^{4}$ Department of Pediatrics, Hematology and Oncology, Medical University of Warsaw, Po- \\ land; ${ }^{5}$ Department of Pediatric Hematology and Oncology, Medical University of Lublin, Poland;

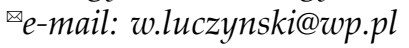

Received: 18 November, 2005; revised: 22 March, 2006; accepted: 19 April, 2006 available on-line: 29 May, 2006

\begin{abstract}
Despite the very high percentage of long-term remissions in acute lymphoblastic leukemia (ALL) in children, some of them suffer from recurrence of the disease. New treatment modalities, e.g. effective geno- and immunotherapy are needed. The use of neoplasmatic cells to present tumor antigens is one of the approaches in cancer vaccines. ALL cells lack the expression of costimulatory molecules and are poor antigen presenting cells (APCs) for T-cell activation. CD40/40L interaction stimulates B-cells to proliferate, differentiate, upregulate costimulatory molecules and increase antigen presentation. The aim of the study was to test the hypothesis that ALL cells can be turned into professional APCs by CD40L activation. Children with B-cell precursor ALL were enrolled into the study. Mononuclear cells from bone marrow or peripheral blood were stimulated with CD40L and interleukin 4. Results: 1) after culture we noted upregulation of all assessed costimulatory, adhesion and activatory molecules i.e. CD1a, CD11c, CD40, CD54, CD80, CD83, CD86, CD123, HLA class I and II; 2) CD40L activated ALL cells induced proliferation of allogeneic T-cells (measured by $\left[{ }^{3} \mathrm{H}\right]$ thymidine incorporation). These results confirm the possibility of enhancing the immunogenicity of ALL cells with the CD40L system and indicate that this approach can be used in immunotherapeutic trials.
\end{abstract}

Keywords: acute lymphoblastic leukemia, CD40L, T-lymphocytes, dendritic cells, immunotherapy

\section{INTRODUCTION}

Despite the very high percentage $(>80 \%)$ of long-term remissions in ALL in children, some of them do suffer from recurrence of the disease. In these cases one of the therapeutic approaches is allogeneic transplantation but it is burdened with high toxicity and mortality. Therefore new treatment modalities, e.g. effective geno- and immunotherapy are needed.

Among all APCs, dendritic cells are the most potent stimulators of T-cell response and play a crucial role in antitumor immunity. It is now accepted that two signals are required to initiate the response of T-lymphocytes against cancer cells. The first one is associated with HLA, the second - with the presence of costimulatory molecules of the B7 family (CD80, CD86) on the APCs. One of the major problems of immunotherapy in leukemias is low expression of costimulatory and adhesion molecules and secretion of immunosuppressive cytokines, e.g. IL-10 by neoplasmatic cells (Kebelmann-Betzing et al., 2001). Antigen presentation in the absence of costimulation is likely to induce anergy and may be one of the mechanisms of escape from immune surveillance (Todisco et al., 2002). Some authors propose transfection of costimu-

Abbreviations: ALL, acute lymphoblastic leukemia; AML, acute myeloid leukemia; APC, antigen presenting cell; B-CLL, B-chronic lymphocytic leukemia; BCP, B-cell precursor; CD40L, CD40 ligand; DCs, dendritic cells; HLA, human leukocyte antigen; IL-4, interleukin 4; MDC, myeloid dendric cells; MLR, mixed lymphocyte reaction; TARC, thymus and activation-regulated chemokine. 
latory molecules into blast cells, but the efficiency and safety of this approach is still to be confirmed (Lee et al., 2001). B-cell precursor ALL cells lack the expression of costimulatory molecules and are poor APCs for T-cell activation (D'Amico et al., 2004). CD40 and its ligand are members of the tumor necrosis factor family. The CD40/40L interaction stimulates normal B-cells to proliferate, differentiate, upregulate costimulatory molecules and increase antigen presentation (von Bergwelt-Baildon et al., 2004). Previously we observed down-regulation of HLA and costimulatory molecules (B7 family) on monocytes from peripheral blood in children with leukemias and lymphomas (Łuczyński et al., 2004). The aim of the present study was to test the hypothesis that BCP-ALL cells can be turned into professional APCs by CD40L activation.

\section{MATERIAL AND METHODS}

Patients. B-cell precursor acute lymphoblastic leukemia (BCP-ALL) is the most common cancer in pediatric patients and is also an important target for immunotherapy. Leukemia is diagnosed when neoplasmatic infiltration of bone marrow is greater than $30 \%$. Children with BCP-ALL were prospectively enrolled into the study $(\mathrm{n}=23,14$ boys, 9 girls, aged $6.25 \pm 4.52$ ). Patients were treated in departments of pediatric hematology and oncology in Białystok, Warszawa and Lublin, Poland according to the protocol recommended by the Polish Pediatric Leukaemia / Lymphoma Study Group, ALL IC 2002 (September 2005 to January 2006). During remission induction the following drugs were administered: prednisone $\left(60 \mathrm{mg} / \mathrm{m}^{2}\right.$, days $\left.1-33\right)$, vincristine $\left(4 \times 1.5 \mathrm{mg} / \mathrm{m}^{2}\right)$, daunorubicin $\left(4 \times 20 \mathrm{mg} / \mathrm{m}^{2}\right)$ and L-asparaginase $(8 \times$ $5000 \mathrm{U} / \mathrm{m}^{2}$ ). Peripheral blood samples or bone marrow were taken at the time of diagnosis, before any treatment. Bone marrow was taken when more than $80 \%$ of blast infiltration was present, peripheral blood - when the leukocyte count was more than $10 \times 10^{9}$ leukocyte/ 1 and blasts accounted for over $50 \%$ in differential white blood cell count. The institutional review board approved this study and informed consent was obtained from patients and their parents.

Cells and culture conditions. Mononuclear cells from bone marrow or peripheral blood samples were isolated after centrifugation over a Ficoll density gradient (Histopaque 1077, Sigma), washed three times in phosphate-buffered saline (PBS) and immediately cryopreserved in RMPI-1640 50\%, fetal bovine serum (FBS) $40 \%$ and dimethyl sulfoxide (DMSO) 10\% (all purchased from Sigma). Vials were first placed in a Freezing Container (Sigma) at $-80^{\circ} \mathrm{C}$ for $24 \mathrm{~h}$ and then stored in liquid nitrogen. After thawing ALL cells were washed, resuspended in medium contaning RMPI-1640 90\%/FBS 10\% („me- dium"), cultured in 24-well flat-bottom plates at a concentration of $1 \times 10^{5} / \mathrm{ml}$ and stimulated (or not) with CD40L $(3 \mu \mathrm{g} / \mathrm{ml}$, a kind gift of Immunex/Amgen, USA) and IL-4 (80 ng/ml, Sigma) (CD40L+IL$4=$ "cytokines"). This combination was chosen after extensive literature reviewing and is the most often used in such experiments. The cells were incubated in a total volume of $1 \mathrm{ml} /$ well at $37^{\circ} \mathrm{C}$ in $5 \% \mathrm{CO}_{2}$ for $96 \mathrm{~h}$. On day 5 (after culture) the cells were harvested and concentrated for flow cytometry and MLR. The trypan blue dye (Sigma) exclusion assay was used to study viability, all assessed samples had at least $80 \%$ viable cells before and after culture.

Flow cytometry. The following fluorescein isothiocyanate (FITC)-, phycoerythrin (PE)- or peridinin chlorophyll protein (PerCP)-conjugated monoclonal antibodies (and isotype controls) were used: CD1a, CD10, CD11c, CD19, CD40, CD45, CD54, CD80, CD83, CD86, CD123, HLA class I, HLA-DR (all purchased from Beckton Dickinson, USA). A total of $10^{5}$ cells were incubated with monoclonal antibodies for $30 \mathrm{~min}$ at $4^{\circ} \mathrm{C}$, washed twice and analysed on an EPICS XL (Coulter) flow cytometer. Percentages of positive cells were calculated.

Mixed lymphocyte reaction (MLR). T-cells were separated from peripheral blood of healthy donors using MACS system (Miltenyi Biotec, USA). In 15 cases after culture leukemic cells were irradiated at $30 \mathrm{~Gy}$ and added as stimulators to $1 \times 10^{5}$ allogeneic $\mathrm{T}$ lymphocytes in triplicates (1:3 ratio). T-cells (all from one healthy donor) were cultured with: 1) blasts treated with "medium" and "cytokines", 2) blasts treated with "medium" alone, 3) concanavalin A as a positive control $(5 \mu \mathrm{g} / \mathrm{ml})$. All specimens were incubated in RPMI-1640/FBS (final volume $200 \mu \mathrm{l}$ ) at $37^{\circ} \mathrm{C}$ in $5 \% \mathrm{CO}_{2}$ for 4 days. Eighteen hours before end of culture cells were pulsed with $1 \mu \mathrm{Ci}$ of $\left[{ }^{3} \mathrm{H}\right]$ thymidine (Amersham, USA). Thymidine incorporation was measured on a $\beta$-counter and expressed as the arithmetic mean c.p.m. of triplicate cultures.

Statistics. Statistical analysis was performed using Statistica 6.0 for Windows. The results were not normally distributed and are expressed as median and 25-75th percentiles. Significance levels were calculated according to the nonparametric Wilcoxon test (comparison between results obtained before and after stimulation with cytokines and between groups stimulated with cytokines and medium alone). The level of $P<0.05$ was regarded as significant.

\section{RESULTS}

Flow cytometry

Main results concerning flow cytometry are listed in Table 1. 
Table 1. Percentages of cells before and after culture in "medium" with or without "cytokines" expressed as median (and 25th-75th percentile in brackets).

\begin{tabular}{|c|c|c|c|c|c|c|}
\hline & I & II & III & & Statistics & \\
\hline & $\begin{array}{l}\text { after thawing } \\
\text { (\% of cells) }\end{array}$ & $\begin{array}{l}\text { cultured with } \\
\text { „medium" } \\
\text { (\% of cells) }\end{array}$ & $\begin{array}{c}\text { cultured with "me- } \\
\text { dium" + CD40L + IL-4 } \\
\text { (\% of cells) }\end{array}$ & I vs II & I vs III & II vs III \\
\hline HLA I class ${ }^{+}$ & $\begin{array}{c}79.0 \\
(66.0-89.0)\end{array}$ & $\begin{array}{c}80.0 \\
(75.0-85.0)\end{array}$ & $\begin{array}{c}85 \\
(83.0-89.0)\end{array}$ & - & $P=0.04$ & $P=0.001$ \\
\hline $\mathrm{HLA} \mathrm{DR}^{+}$ & $\begin{array}{c}64.0 \\
(53.0-73.0)\end{array}$ & $\begin{array}{c}66.5 \\
(60.5-79.0)\end{array}$ & $\begin{array}{c}71.5 \\
(65.5-82.5)\end{array}$ & - & $P=0.01$ & $P=0.009$ \\
\hline $\mathrm{CD}_{40}^{+}$ & $\begin{array}{c}24.0 \\
(13.0-38.0)\end{array}$ & $\begin{array}{c}38.0 \\
(30.0-49.0)\end{array}$ & $\begin{array}{c}58.0 \\
(43.0-68.0)\end{array}$ & $P=0.01$ & $P=0.00002$ & $P=0.00004$ \\
\hline $\mathrm{CD} 83^{+}$ & $\begin{array}{c}18.0 \\
(9.0-31.0)\end{array}$ & $\begin{array}{c}38.0 \\
(33.0-49.0)\end{array}$ & $\begin{array}{c}58.0 \\
(52.0-65.0)\end{array}$ & $P=0.004$ & $P=0.000069$ & $P=0.0001$ \\
\hline $\mathrm{CD} \mathrm{a}^{+}$ & $\begin{array}{c}6.0 \\
(4.0-10.0)\end{array}$ & $\begin{array}{c}12.0 \\
(9.0-16.0)\end{array}$ & $\begin{array}{c}23.0 \\
(17.0-29.0)\end{array}$ & $P=0.0003$ & $P=0.00006$ & $P=0.00008$ \\
\hline $\mathrm{CD} 4^{+}$ & $\begin{array}{c}7 \\
(4.8-12.9)\end{array}$ & $\begin{array}{c}11.0 \\
(8.0-13.0)\end{array}$ & $\begin{array}{c}23.0 \\
(17.0-28.0)\end{array}$ & - & $P=0.00006$ & $P=0.00006$ \\
\hline $\mathrm{CD} 80^{+}$ & $\begin{array}{c}5.0 \\
(1.1-8.9)\end{array}$ & $\begin{array}{c}7.0 \\
(4.2-13.0)\end{array}$ & $\begin{array}{c}16.0 \\
(11.0-19.0)\end{array}$ & - & $P=0.0001$ & $P=0.0001$ \\
\hline $\mathrm{CD} 86^{+}$ & $\begin{array}{c}14.0 \\
(4.5-21.0)\end{array}$ & $\begin{array}{c}20.0 \\
(14.0-27.0)\end{array}$ & $\begin{array}{c}30.0 \\
(23.9-46.0)\end{array}$ & $P=0.009$ & $P=0.00049$ & $P=0.00006$ \\
\hline $\mathrm{CD}_{123^{+}}$ & $\begin{array}{c}0.2 \\
(0.1-0.7)\end{array}$ & $\begin{array}{c}0.7 \\
(0.1-1.4)\end{array}$ & $\begin{array}{c}2.1 \\
(0.9-3.1)\end{array}$ & $P=0.0098$ & $P=0.00006$ & $P=0.00036$ \\
\hline $\mathrm{CD}_{11 \mathrm{c}^{+}}$ & $\begin{array}{c}0.2 \\
(0.1-0.4)\end{array}$ & $\begin{array}{c}0.6 \\
(0.4-0.9)\end{array}$ & $\begin{array}{c}1.8 \\
(1.4-2.5)\end{array}$ & $P=0.003$ & $P=0.00002$ & $P=0.0001$ \\
\hline $\mathrm{CD} 80^{+} \mathrm{CD} 86^{+}$ & $\begin{array}{c}5.05 \\
(1.85-10.0)\end{array}$ & $\begin{array}{c}13.1 \\
(8.9-18.5) \\
\end{array}$ & $\begin{array}{c}12.0 \\
(7.5-13.5)\end{array}$ & $P=0.001$ & $P=0.0006$ & - \\
\hline
\end{tabular}

1) After thawing, before culture, ALL cells were mostly negative for CD123 and CD11c $(<1.0 \%$ positive cells), moderately positive for CD40, CD83, CD1a, CD54, CD80 and CD86 (5-25\%) and highly positive for HLA class I and II $(>60 \%)$.

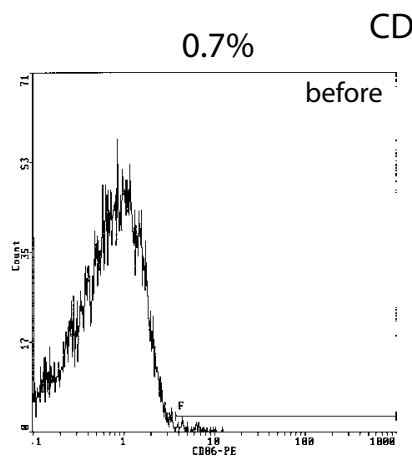

CD86
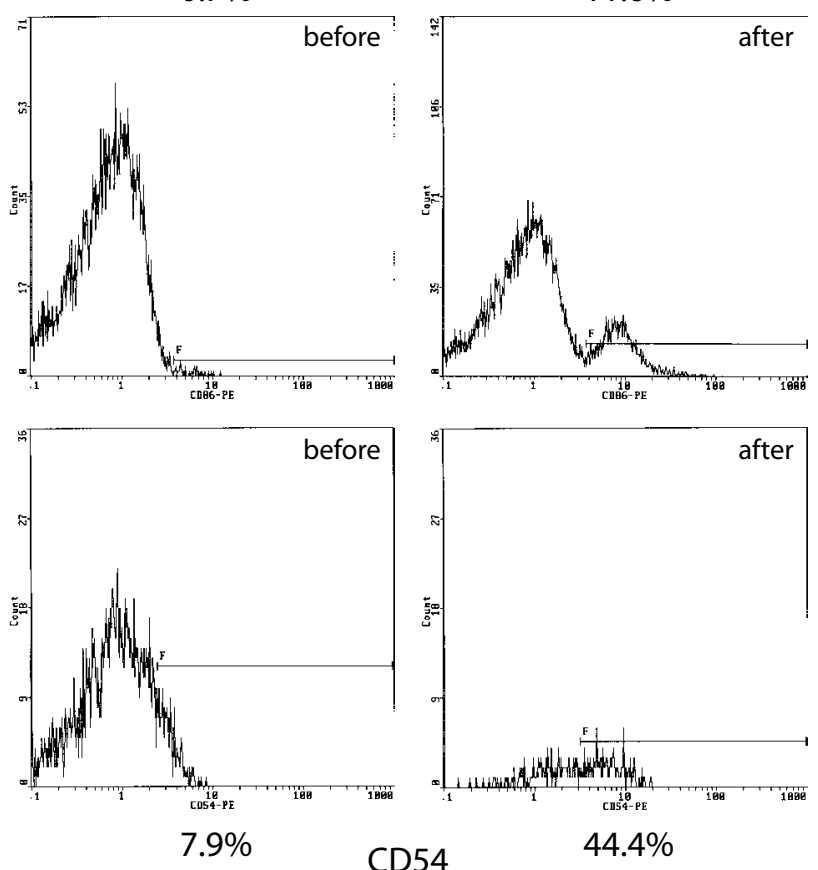

2) After culture, a statistically significant rise in all assessed cell populations was noted - example - Fig. 1. In some populations this increase was also observed in cells treated with ",medium” alone, i.e. CD1a, CD11c, CD40, CD83, CD86, CD123. How-

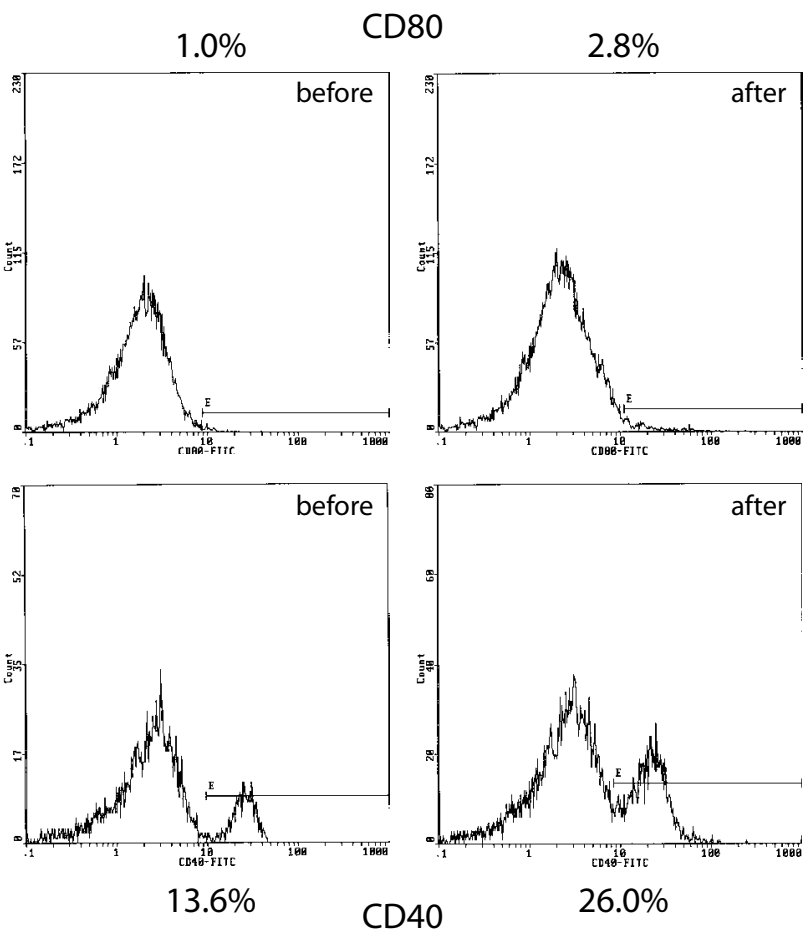

Figure 1. Percentages of acute lymphoblastic leukemia cells before and after culture with "cytokines" - an example. 


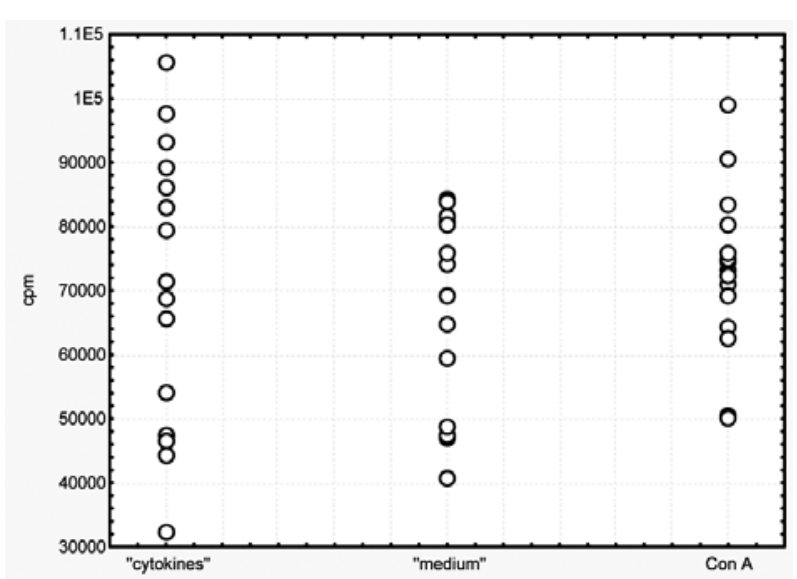

Figure 2. $\left[{ }^{3} \mathrm{H}\right]$ Thymidine incorporation after mixed lymphocyte culture.

Allogeneic T-cells were incubated with: concanavalin A (Con A), blasts treated with CD40L+IL-4 („,cytokines") and blasts treated with medium alone („medium”).

ever, in all cases we also found statistically significant differences between the percentages of positive cells treated with "cytokines" vs. those treated with "medium" alone.

\section{$\left[{ }^{3} \mathrm{H}\right]$ thymidine incorporation}

We did not find any statistically significant differences in proliferation of T-cells among the three assessed groups but a slight tendency was observed: $\left[{ }^{3} \mathrm{H}\right]$ thymidine uptake was high after culture with concavalin A (control stimulator), lower - after MLR with blasts cultured with "medium" and "cytokines", and the lowest after MLR with blasts cultured only with „medium” (Fig. 2).

\section{DISCUSSION}

The culture conditions and the cytokines used in our study were very similar to those used in experiments of Hoogendoorn et al. (2004), Cignetti et al. (1999) and other researchers and are considered to be optimal for high expression of costimulatory molecules and high viability of leukemic cells in 96 $\mathrm{h}$ culture. In contrast, Lee et al. (2004) tested four different cytokine combinations and regard CD40L+IL$1 \beta+$ IL-3+IL-7+TNF- $\alpha+$ SCF as a most effective combination in upregulating costimulatory molecules. Other authors tried to combine CD40L with IL-3 in long-term cultures of BCP-ALL cells. This combination increased the proliferation of neoplasmatic cells by up-regulating expression of IL-3 receptor (Zhou et al., 2000). In another study effective generation of autologous cytotoxic T-cell lines secreting IFN- $\gamma$ in response to B-CLL cells required combination of CD40L and OX40L - a molecule involved in expan- sion of memory antigen-specific T-cells (Biagi et al., 2005).

We found high expression of HLA molecules and low expression of costimulatory molecules after thawing of BCP-ALL cells. Similar to our observations, Cignetti et al. (1999) observed high expression of HLA class I and II, moderate of CD40, CD83 and CD86 and low expression of CD1a and CD80 on blast cells before culture. After CD40L and IL-4 stimulation the expression of CD80, CD83 and CD86 increased significantly (as in our study), but in contrast to our results, HLA class I and DR did not rise significantly and CD1a expression remained negative. In their opinion the most important goal was to achieve increased expression of the costimulatory molecules of the B7 family: CD80 and CD86. This goal was obtained in our experiment but, surprisingly, culture with "medium" alone also resulted in up-regulation of almost all assessed molecules. This could be the effect of non-specific stimulation during culture. A higher expression of B-7 family molecules after $24 \mathrm{~h}$ culture with "medium" alone was reported by Urbaniak-Kujda et al. (2004) in AML but not in ALL cells. Very interesting results were recently obtained by Lee et al. (2004). These authors showed that only the $\mathrm{CD} 80^{+} \mathrm{CD} 86^{+}$subpopulation of leukemia-derived dendritic cells are mature DCs and can induce allogeneic T-cell proliferation. In our study there was no difference between the percentages of $\mathrm{CD}^{2} 0^{+} \mathrm{CD} 86^{+}$cells after culture with or without CD40L and IL-4. This may be the reason why we did not see significant differences in MLR between those two groups. In contrast to our observations, Hoogendoorn et al. (2004) did not observe the proliferation of allogeneic T-cells using primary B-CLL as stimulators and only CD40L-activated cells were able to stimulate T-mediated response. Interestingly, allogeneic human bone marrow stroma (HBMS) was able to induce modulation of HLA, adhesion and costimulatory molecules on ALL cells, but not CD80 (Todisco et al., 2002). Those authors summarize that allogeneic T-cells responsiveness to BCP-ALL cells can be induced by simple contact with the stroma and CD40L only improves this effect. Similar results concerning the upregulation of costimulatory molecules (CD80 and CD86) during co-culture with HBMS were obtained by D'Amico et al. (2004). The further stimulation with CD40L increased this effect, as in our study. Those authors observed expression of the chemotactic receptor CCR7 and migration in response to CCL19 only after CD40 engagement. The mechanism of this phenomenon remains to be investigated.

In another study ALL-cells after CD40L+IL4 activation remained CD1a negative (Mohty et al., 2002). High expression of the adhesion molecule CD54 (ICAM-1) seems to play an important role in 
anti-leukemic immunity because some authors report a positive correlation between survival and the presence of this molecule on blast cells (Mielcarek et al., 1997). In our series only $24 \%$ ALL cells expressed CD40 after thawing. According to Todisco et al. (2002) more than $50 \%$ ALL cells were CD40 positive originally and almost $100 \%$ after CD40L stimulation. Also other investigators found high expression of CD40 and, surprisingly, CD40L (not assessed in our experiment) on blast cells (Kebelmann-Betzing et al., 2001).

In the study by Cignetti et al. (1999) leukemiaderived DC stimulated proliferation response to a greater extend than original leukemic blasts. In our study T-cells were stimulated comparably by leukemia-derived DCs and original blasts treated without "cytokines". A tendency to higher proliferation of Tcells after culture with concanavalin A comparing to T-cells stimulated with blasts after culture with "medium" alone was observed.

Lee et al. (2001) using an embryonic kidney cell line transfected with CD154 (CD40L) achieved up-regulation of crucial costimulatory molecules (i.e. HLA class I and II, ICAM, LFA, CD80, CD86) on blast cells and MLR response also against wild-type autologous ALL cells (not treated with cytokines). The authors believe that CD40-mediated activation of ALL cells could form the basis of immunotherapy against residual ALL cells after achieving remission (Lee et al., 2001). This could reduce recurrences of the disease. Some authors propose that autologous immunotherapy in $t(9 ; 22)$ ALL should be used simultanously with imatinib (Lee et al., 2004). Ghia et al. (2001) demostrated that CD40 cross-linking (CD40-FLAG-tag fusion protein supplemented with CD40L enhancer) not only improves tumor cell immunogenicity but also induces potent chemoattraction for T-cells, i.e. secretion of CC-chemokines: MDC and TARC.

The type of anticancer T-cell response after CD40L activation seems to be very important in eradication of leukemic cells. Combination of CD40L and IL-4 resulted not only in exhibition of the DC phenotype and proliferative response (as in our study) but also in secretion of $\mathrm{Th}_{1}$ cytokines and IFN- $\gamma$ (Mohty et al., 2002). In one study CD40L activated BCP-ALL cells were unable to generate the $\mathrm{Th}_{1}$ profile (IFN- $\gamma$ production), instead they promoted T-cell anergy and IL-10 production. Initially the proliferation of allogeneic T-cells was observed but it did not last. Addition of IL-2 did not revert this anergy, but addition of IL-12 induced the $\mathrm{Th}_{1}$ response. The authors conclude that activation of the CD40 pathway alone is not enough to be used in cancer vaccines and suggest the use of additional signals after CD40L stimulation to induce a protective anti-cancer immune response ( $\mathrm{D}^{\prime}$ Amico et al.,
2004). Interestingly, gene-modified ALL cells (transduced with CD40L, CD80 and GM-CSF) were rejected from mice only in the presence of NK cells, confirming participation of these cells in anti-cancer immunity (Gruber et al., 2002).

All the papers discussed above concerned laboratory data. Very recently a phase I trial with CD40L-ALL vaccine was conducted (Haining et al., 2005). Haining and coworkers successfully prepared autologous vaccines for children with second or third relapse but unfortunately most of the patients died or progressed before vaccination (median time - 29 days). In their opinion it is not possible to define the window of immune recovery (i.e. time of vaccination) not only in patients with relapse but also in newly diagnosed patients because most of them did not attain CD4 count over $500 \mathrm{CD} 4 / \mu \mathrm{l}$ during 2 years of treatment. We do not agree with this statement. Our previous results also showed lower CD4/CD8 ratio and slow increase during maintenance treatment for ALL, but a very rapid recovery after the end of conventional chemotherapy (Euczyński et al., 2004). We think that trials with CD40L-activated ALL-cells should be further conducted and children with high-risk should be vaccinated despite immunesuppression, like children in other diseases with impaired immunity, e.g. renal insufficiency.

In summary, we and other authors showed that CD40L activation of ALL cells can induce them into dendritic cells and could be used in the future as a cancer vaccine. According to $\mathrm{D}^{\prime}$ Amico et al. (2004) at least three different groups of patients could benefit from this approach: 1) children after hemopoietic stem cell transplantation (eradication of minimal residual disease), 2) children with primary disease resistant to conventional treatment, 3) patients in low-risk group (reduction of toxic chemotherapy). The main advantage of our system is that it does not require genetic manipulation of neoplasmatic cells. In our opinion CD40/CD40L immunotherapy has still to be optimized and developed in clinical conditions but the laboratory results are promising.

\section{REFERENCES}

Biagi E, Dotti G, et al. (2005) Molecular transfer of CD40 and OX40 ligands to leukemic human B cells induces expansion of autologous tumor-reactive cytotoxic $\mathrm{T}$ lymphocytes. Blood 105: 2436-2442.

Cignetti A, Bryant E, Allione B, Vitale A, Foa R, Cheever MA (1999) CD34+ acute myeloid and lymphoid leukemic blasts can be induced to differentiate into dendritic cells. Blood 94: 2048-2055.

D'Amico G, Bugarin MV, Bianchi G, Pirovano G, Bonamino M, Marin V, Allavena P, Biagi E, Biondi A (2004a) CD40 activation of BCP-ALL cells generates IL-10 pro- 
ducing, IL-12 defective APCs that induce allogeneic Tcell anergy. Blood 104: 744-751.

D’Amico G, Marin V, Biondi A, Bonamino MH (2004b) Potential use of CD40 ligand for immunotherapy of childhood B-cell precursor acute lymphoblastic leukaemia. Best Pract Res Clin Hematol 17: 465-477.

Ghia P, Transidico P, et al. (2001) Chemoattractants MDC and TARC are secreted by malignant B-cell precursors following CD40 ligation and support the migration of leukemia-specific T-cells. Blood 98: 533-540.

Gruber TA, Skelton DC, Kohn DB (2002) Requirement for NK cells in CD40 ligand-mediated rejection of Philadelphia chromosome-positive acute lymphoblastic leukemia cells. J Immunol 168: 73-80.

Haining WN, Cardoso AA, et al. (2005) Failure to define window of time for autologous tumor vaccination in patients with newly diagnosed or relapsed acute lymphoblastic leukemia. Exp Hematol 33: 286-294.

Hoogendoorn M, Wolbers JO, Smit WM, Schaafsma MR, Barge RMY, Willemze R, Falkenburg JHF (2004) Generation of B-cell chronic lymphocytic leukemia (BCLL)-reactive T-celll lines and clones from HLA class I-matched donors using modified B-CLL cells as stimulators: implications for adoptive immunotherapy. Leukemia 18: 1278-1287.

Kebelmann-Betzing C, Korner G, Badiali L, Buchwald D, Moricke A, Korte A, Kochling J (2001) Characterization of cytokine, growth factor receptor, costimulatory and adhesion molecule expression patterns of bone marrow blasts in relapsed childhood B cell precursor ALL. Cytokine 13: 39-50.

Lee AJ, Haworth C, Hutchinson RM, Patel R, Carter R, James RFL (2001) Enhancement of cALL immunogenecity by co-culture with a CD154 expressing 293 cell line. Clin Exp Immunol 124: 359-368.

Lee J, Sait SN, Wetzler M (2004) Characterisation of dendritic-like cells derived from $t(9 ; 22)$ acute lymphoblastic leukemia blasts. Int Immunol 16: 1377-1389.

Łuczyński W, Stasiak-Barmuta A, Krawczuk-Rybak M (2004a) Immunologic monitoring of maintenance ther- apy for acute lymphoblastic leukaemia in children preliminary report. Pediatr Blood Cancer 42: 416-420.

Łuczyński W, Stasiak-Barmuta A, Krawczuk-Rybak M, Szymański M, Malinowska I, Mitura-Lesiuk M (2004b) Monocytes in children with leukemias and lymphomas - down-regulation of HLA and costimulatory molecules. Acta Biochim Polon 51: 1067-1073.

Mielcarek M, Sperling C, Schrappe M, Meyer M, Riehm H, Ludwig WD (1997) Expression of intercellular adhesion molecule (ICAM-1) in childhood acute lymphoblastic leukemia: correlation with clinical features and outcome. Br J Haematol 96: 301-307.

Mohty M, Isnardon D, Charbonnier A, Lafage-Pochitaloff M, Merlin M, Sainty D, Olive D, Gaugler B (2002) Generation of potent Th1 responses from patients with lymphoid malignancies after differentiation of B lymphocytes into dendritic cells. Int Immunol 14: 741-750.

Todisco E, Gaipa G, Biagi E, Bonamino M, Gramigna R, Introna M, Biondi A (2002) CD40 ligand-stimulated B cell precursor leukemic cells elicit interferon-gamma production by autologous bone marrow T-cells in childhood acute lymphoblastic leukemia. Leukemia 16: 2046-2054.

Urbaniak-Kujda D, Wołowiec D, Tomaszewska-Toporowska B, Jaźwiec B, Frydecka I, Kapelko-Słowik K, Kuliczkowski K (2004) Wpływ krótkoterminowych hodowli blastów ostrych białaczek na ekspresję cząsteczek kostymulujących i na zdolność indukcji proliferacji autologicznych limfocytów T. Adv Clin Exp Med 13: 567-573.

von Bergwelt-Baildon Mv, Maecker B, Schultze J, Gribben JG (2004) CD40 activation: potential for specific immunotherapy in B-CLL. Ann Oncol 15: 853-857.

Zhou M, Gu L, Holden J, Yeager AM, Findley HW (2000) CD40 ligand upregulates expression of the IL-3 receptor and stimulates proliferation of B-lineage acute lymphoblastic leukemia cells in the presence of IL-3. Leukemia 14: 403-411. 